\title{
Domestic and foreign experience of using soft fitting structures in tent equipment
}

\author{
Boris Strigin * \\ Moscow State University of Civil Engineering, Yaroslavskoe shosse, 26, Moscow, 129337, Russia
}

\begin{abstract}
This research is review of purpose like soft enclosing structures made of different types of awning material: structural (construction of awning materials, solid (stretching and rupture) and lighting engineering (light transmission, light reflection). These researches are shown in following: graphs, tables, shorts. The prospect of development this type of construction is reviled on domestics and foreign examples of awning material. Results of studies are presented in the form of graphs and tables on the study of physical and mechanical properties of domestic tent materials and a comparative analysis of domestic and foreign experience in the use of these materials in tent structures.
\end{abstract}

\section{Introduction}

\begin{abstract}
"Nothing in Rome, not even a gladiatorial battle, was as surprising as a giant awning stretched over the Colosseum." These words were made in the first century AD by the ancient Roman historian Pliny the Elder. As can be seen, the history of soft enclosing structures and tent structures is not so young. An important milestone in the modern development of such structures was the turn of the 20th-21st centuries. During this period, F. Otto began to create awning and membrane structures, at the same time this direction was developed by the specialists of the Moscow State University of Civil Engineering (National Research University MSUCE) [1]. In this paper we study the physical and mechanical properties of tent materials, examples of domestic and foreign tent structures and draw conclusions about the prospects for their development in Russia.

The popularity of tent structures is determined by their undeniable advantages (ease, mobility), the possibility of giving non-traditional forms and matching modern economic trends [2]. Based on the analysis of history and modern experience, the following areas of application of awning: pneumatic, cable and membrane structures are distinguished: agrarian industry and agriculture, tent shelters for drilling rigs, tents for welding operations, universal and large-span prefabricated awnings, car park, airport and landing canopies platforms, car washes, warehouses for storage of materials and products, hangars for maintenance and storage of machinery and equipment, air hangars, summer cafe sheds, cinemas theaters, dance floors, entrance groups, arenas for different purposes, scenes collapsible and stationary for cultural events, stage platforms, shadow canopies, and ready-
\end{abstract}

\footnotetext{
Corresponding author: stryginbs@mail.ru
} 
made arbors and verandas for kindergarten sites, circus covers (circus tents), sports facilities . On the basis of the constructive feature, the following main types of structures can be distinguished with the use of MO: awning, cable-tent, cable roofing of cable systems, pneumatic structures [3].

\section{Methodology}

In the process of research, the physico-mechanical characteristics of domestic tent materials were determined, and the domestic experience was analyzed on the example of the most significant projects of tent constructions. Based on the results of studying foreign sources, the main achievements and trends in the development of tent constructions abroad were singled out and examined on specific examples. Based on the results of laboratory and fullscale tests, conclusions were drawn about the main properties of some materials of soft enclosing structures.

\subsection{First constructions with application of tent coverings}

One of the first buildings in which the awning covers were used in the USSR were circus tents. For example, circus tent in Gorky Park for 1200 seats developed by IISI staff for the Olympics-80. Another outstanding project is a space-barrel dome with a diameter of $43 \mathrm{~m}$. and a height of $12.5 \mathrm{~m}$. with a tent walling suspended from the bottom (TM-B "Volga"), serving as a public centre for multi-purpose use in the international tourist camp "Volga". The next object developed by the staff of the National Research University MSUCE in conjunction with the KSCU, on the instructions of the Government of Tatarstan, was a set of tent structures in the historian-cultural centre of Bulgara near Kazan. Architect is Sladkov Valentin Alexandrovich, chief engineer is Strigin Boris Sergeevich (Figure 1).

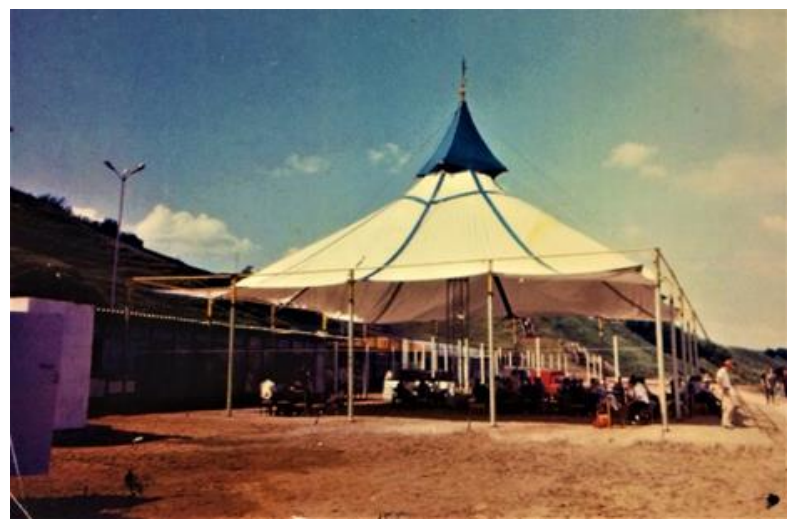

Fig. 1. The complex of awning structures in the historian-cultural centre of Bulgara near Kazan.

A great contribution to the study of the physical and mechanical properties of awning materials used as soft enclosing structures in awning structures, which will be discussed below, was made by $\mathrm{PhD}$ in Engineering sciences., associate professor of the National Research University MSUCE Strigin B.S., conducted in the international tourist camp "Volga "on the basis of multifunctional public centre. It is a visual proof that the awning structures are the best solution for civil and recreational buildings. In modern society, soft enclosing structures are widely used in the manufacture of hangars, sports facilities, public 
catering establishments, as well as for individual design tasks. The important milestone in the development of the Ministry of Defense of Russia was the development of high-strength self-extinguishing tent materials, developed including employees of the Moscow University of Civil Engineering Blinov Y.I. and associate professor Strigin B.S. So, for example, tent material (TM-B), "vinylskozhu" -T. The tests showed high tensile strength $(300 \mathrm{~kg}$ per 5 $\mathrm{cm}$ ) and stability of performance (service life -25 years), as well as a variety of colors and shades with different light transmittance factors (see Table 1, Figure 2).

Table 1. Light technical characteristics of fabric-film materials.

\begin{tabular}{|c|c|c|c|c|c|c|c|c|c|}
\hline \multirow[t]{3}{*}{ No. } & \multirow{3}{*}{$\begin{array}{c}\text { The } \\
\text { graphics } \\
\text { on Figure } \\
2\end{array}$} & \multirow{3}{*}{$\begin{array}{c}\text { Name of TM, GOST, TU, } \\
\text { manufacturer, condition, } \\
\text { color }\end{array}$} & \multirow{3}{*}{$\begin{array}{c}\text { Structural schemes } \\
\text { of TM }\end{array}$} & \multicolumn{6}{|c|}{ Light technical characteristics, $\%$} \\
\hline & & & & \multicolumn{4}{|c|}{ FSHM-56M } & \multicolumn{2}{|c|}{ HITACHI } \\
\hline & & & & $\tau$ & $\rho$ & $\alpha$ & $\beta$ & $\tau$ & $\rho$ \\
\hline 1 & 5 & $\begin{array}{l}\text { "Teza-C", TU-17-21-231- } \\
78 \text { IvVNIIPIK, Ivanovo, } \\
\text { new, white-washed color }\end{array}$ & ias & 30 & 52 & 18 & $\begin{array}{l}0,57 \\
\left(d^{*}\right)\end{array}$ & 25 & 52 \\
\hline 2 & 16 & $\begin{array}{c}\text { "Thesa", TU-17-21-231- } \\
\text { 78, IvVNIIPIK, Ivanovo, a } \\
\text { new, yellow color }\end{array}$ & & 2 & 43 & 55 & $\begin{array}{c}0,49 \\
\text { (d) }\end{array}$ & - & 50 \\
\hline 3 & $16 \mathrm{c}$ & $\begin{array}{l}\text { "Thesa", TU-21-231-78, } \\
\text { IvVNIIIPK, Ivanovo, } \\
\text { aging } 2 \mathrm{~g} \text {, yellow color }\end{array}$ & कing & 2 & 39 & 59 & $\begin{array}{c}0,52 \\
\text { (d) }\end{array}$ & - & 33 \\
\hline 4 & 75 & $\begin{array}{l}\text { "Volga-1", experimental, } \\
\text { new, green-green color }\end{array}$ & seses & 6 & 48 & 46 & $\begin{array}{c}0,60 \\
\text { (d) }\end{array}$ & - & 46 \\
\hline 5 & 76 & $\begin{array}{l}\text { "Volga-1", experimental, } \\
\text { aging } 2 \mathrm{~d} \text {, t-brown color }\end{array}$ & m2:8 & 1 & 15 & 84 & $\begin{array}{c}0,47 \\
(d)\end{array}$ & - & 17 \\
\hline 6 & 29 & $\begin{array}{l}\text { "Volga-3", Art. 1146, rd } \\
\text { RTI, Yaroslavl, new, gray } \\
\text { color }\end{array}$ & 20:98. & 03 & 28 & 72 & $\begin{array}{c}0,41 \\
\text { (d) }\end{array}$ & - & 22 \\
\hline 7 & 21 & $\begin{array}{l}\text { PVC mark "T", EPKTB } \\
\text { "Stroyplastik", Kiev, } \\
\text { (experimental), new, } \\
\text { transparent, aluminized } \\
\text { color }\end{array}$ & 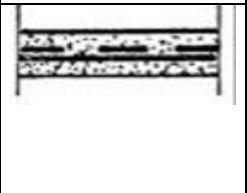 & 49 & 40 & 11 & 265 & 52 & 32 \\
\hline 8 & 22 & $\begin{array}{l}\text { PVC mark "T", EPKTB } \\
\text { "Stroyplastik", Kiev, new, } \\
\text { milky white color }\end{array}$ & $=$ & 37 & 60 & 3 & 168 & 17 & 58 \\
\hline 9 & 24 & $\begin{array}{l}\text { Viniplan, A / O TURO, } \\
\text { Kuopio, Finland, new, } \\
\text { yellow color }\end{array}$ & 201989 & 7 & 67 & 26 & $\begin{array}{c}0,94 \\
\text { (d) }\end{array}$ & - & 60 \\
\hline 10 & 20 & $\begin{array}{c}\text { Canvas tarpaulin, Art. } \\
11124\end{array}$ & & - & 17 & - & 0,50 & - & 15 \\
\hline
\end{tabular}




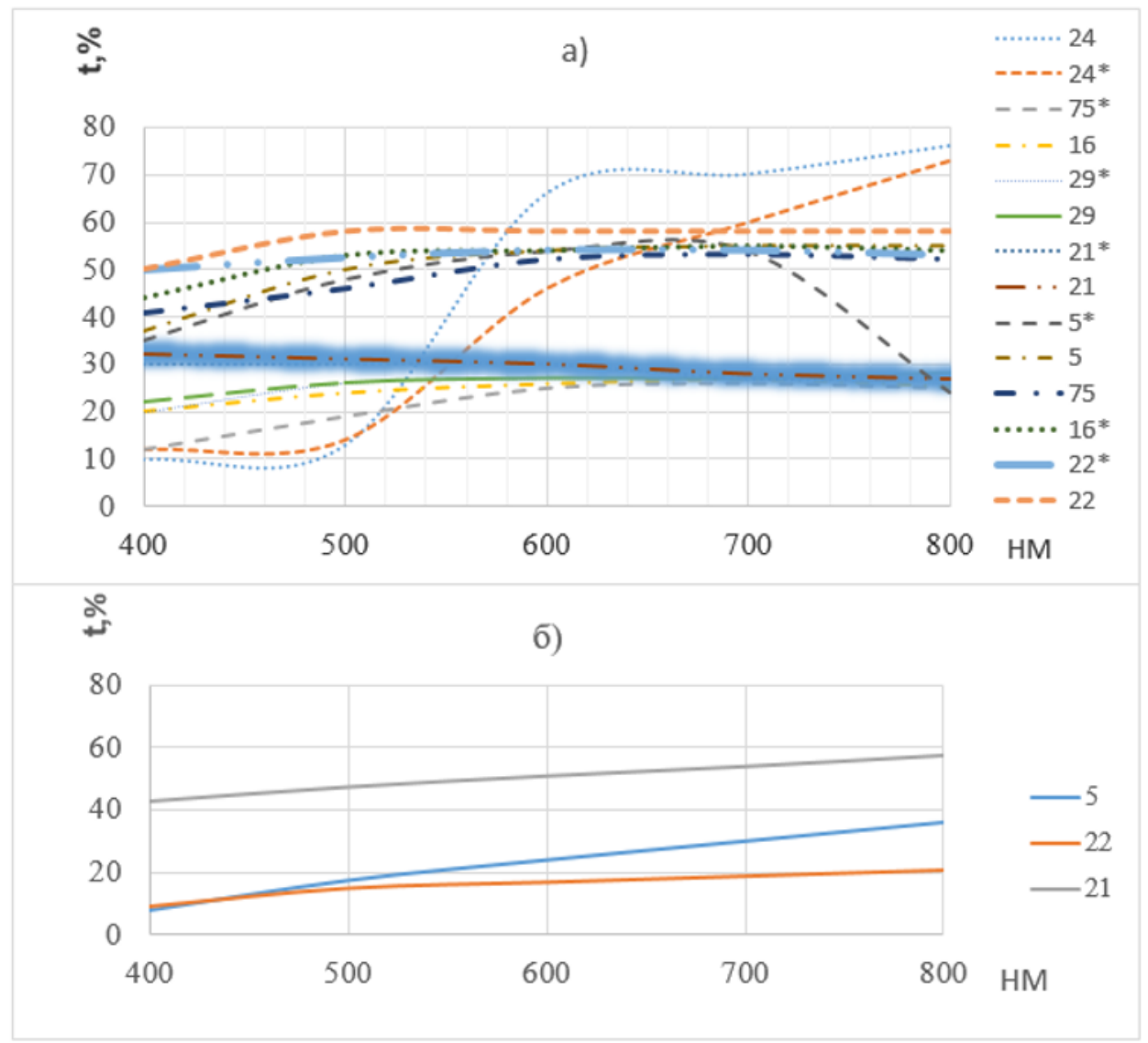

Fig. 2. The graphs of spectral characteristics of TM: a) - reflections $(\rho)$; b) is the transmission $(\tau) .{ }^{*}$ reflection of the inside of the TM. 5 - "Theza-S"; 21 - PVC mark "T" (for external fencing); 22 - PVC mark "T" (for internal fencing); 24 - "Viniplan", see Table 1.

\subsection{Investigation of physical and mechanical properties of tent materials}

Mechanical properties of awning materials are the main ones. determine the existence of tent structures in general. Mechanical properties include the tensile strength of the material, the deformation characteristics of the material, etc. The tensile state of materials under tension is the basis for mechanical calculations of strength and deformation of tent structures, the basis of geometric calculations of the shape and cut of soft shells. The loadstrain relationship for different types of awning materials has its own peculiarities. The chemical basis of the material is its design; the interaction of the material components influences this dependence [15].

According to the nature of the macrostructure of the material, TM-B is a reinforcement base with a polymer coating.

The structure of the reinforcing base should not be considered as an idealized interlacing of warp and weft yarns, but the actual one obtained after technological effects, with the application of a protective polymer coating and its vulcanization. When applying polymer mass in the direction of the base, much greater force is applied than on the weft, as a result of which the warp threads are straightened, and the weft threads are bent. Figure 3 shows a micrograph of a section of awning material on lavsan base with a PVC coating. 


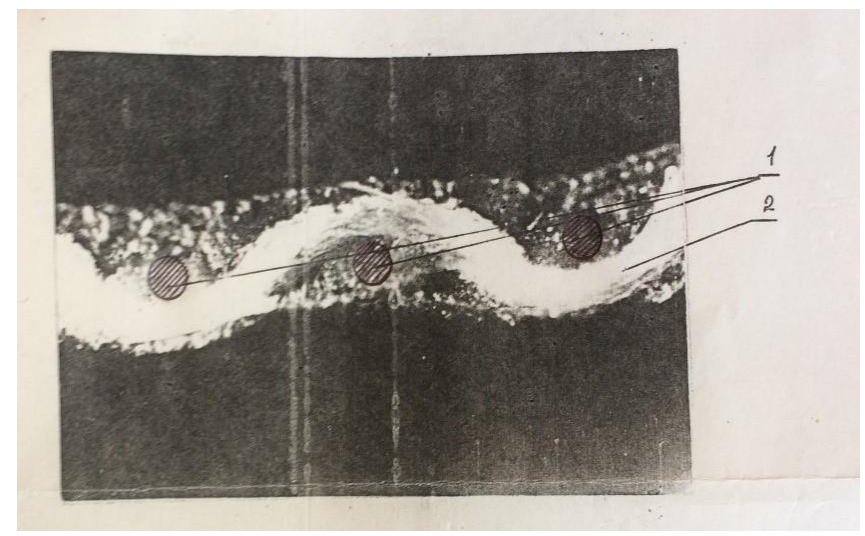

Fig. 3. The microphotograph of section of the tent material: coating-polyvinyl chloride, reinforcing base-lavsan, 1-core threads; 2-weft yarns.

It can be seen, that the warp threads are straight, the curvature of the weft yarn is significant. The latter, in turn, leads to an uneven deposition of the polymer coating on the surface of the tissue. Strength and deformation characteristics of the awning material in the direction of the warp and weft are different. Figure 4 shows a diagram of uniaxial stretching of TM-B material in the direction of the base, weft, and in the diagonal direction.

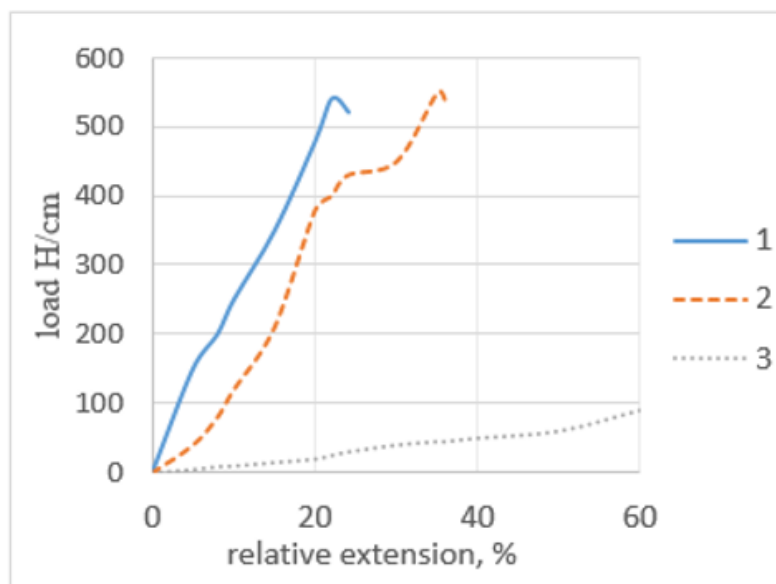

Fig. 4. The diagram of uniaxial stretching of materials TM-B, 1 - in the direction of the base; 2 - in the direction of the duck; 3 - in the diagonal direction.

The results of determining the physico-mechanical characteristics of the material TM-B are given in Table 2. The physical and mechanical characteristics of the material are determined on the German explosive machine ZMGi - $250 \mathrm{kr}$.

Table 2. The physical-mechanical awning material TM-B.

\begin{tabular}{|c|c|c|c|c|c|c|}
\hline Materials & \multicolumn{3}{|c|}{ Strength *, N/cm } & \multicolumn{3}{c|}{ Relative extension*, \% } \\
\cline { 2 - 7 } & $\begin{array}{c}\text { Along roll } \\
\text { (base) }\end{array}$ & $\begin{array}{c}\text { Across the } \\
\text { roll }\end{array}$ & $\begin{array}{c}\text { Diagonally } \\
\text { roll }\end{array}$ & $\begin{array}{c}\text { Along roll } \\
\text { (base) }\end{array}$ & $\begin{array}{c}\text { Across the } \\
\text { roll }\end{array}$ & $\begin{array}{c}\text { Diagonally } \\
\text { roll }\end{array}$ \\
\hline $\begin{array}{c}\text { TM-B red } \\
\text { color }\end{array}$ & 533 & 549 & 94 & 24 & 32,3 & 63,1 \\
\hline $\begin{array}{c}\text { TM-B yellow } \\
\text { color }\end{array}$ & 526 & 504 & 80 & 28,8 & 33,7 & 50,5 \\
\hline
\end{tabular}

* Strength and elongation of materials were obtained by testing 30 samples. 
The statistical characteristics of the physical and mechanical properties of the TM-B tent material are given in Table 3.

Table 3. The static characteristics of physical and mechanical properties of awning material TM-B.

\begin{tabular}{|c|c|c|c|c|c|c|}
\hline Material & \multicolumn{3}{|c|}{ Strength } & \multicolumn{3}{|c|}{ Relative extension } \\
\cline { 2 - 6 } & $\begin{array}{c}\text { The average } \\
\text { value, N/ cm }\end{array}$ & $\begin{array}{c}\text { The average } \\
\text { square } \\
\text { deviation, } \\
\mathrm{N} / \mathrm{cm}\end{array}$ & $\begin{array}{c}\text { The } \\
\text { coefficient } \\
\text { of } \\
\text { variation, } \\
\%\end{array}$ & $\begin{array}{c}\text { The } \\
\text { average } \\
\text { value, } \\
\mathrm{N} / \mathrm{cm}\end{array}$ & $\begin{array}{c}\text { The average } \\
\text { square } \\
\text { deviation, } \\
\mathrm{N} / \mathrm{cm}\end{array}$ & $\begin{array}{c}\text { The } \\
\text { coefficient } \\
\text { of variation, } \\
\%\end{array}$ \\
\hline TM-B, & 533 & 13 & 2,43 & 24 & 0,94 & 3,91 \\
red color & 549 & 14,3 & 2,6 & 32,3 & 0,825 & 2,6 \\
& 94 & 52,8 & 56 & 63,1 & 6,77 & 10,7 \\
TM-B, & 526 & 26,6 & 5,05 & 28,8 & 0,91 & 3,1 \\
yellow color & 504 & 21,3 & 4,2 & 33,7 & 1,75 & 5,2 \\
\hline
\end{tabular}

* Note: in the numerator-value on the basis, in the denominator by duck

For tent materials, tests are carried out in the direction of the base and weft, they basically sweep along the axes of symmetry.

As can be seen from the test results, the properties of materials in different directions are different. The flow direction of the material is more deformable than the base. Strength characteristics of the material in the direction of the base and weft differ slightly. The materials of TM-B are of red color in comparison with the TM-B mate of yellow color more homogeneous, less deformed and has higher strength in the duck direction. The strength of the material decreases sharply and the deformation in the direction of the diagonal increases. The strength in the direction of the diagonal decreases almost 7 times, and the deformability increases by a factor of 2 .

A comparison of the physical-mechanical characteristics of material TM-B and other tent materials is given in Table 4.

Table 4. The static characteristics of physical and mechanical properties of various tent materials.

\begin{tabular}{|c|c|c|c|c|}
\hline \multirow{2}{*}{ Materials } & \multicolumn{2}{|c|}{ Strength } & \multicolumn{2}{c|}{ Relative extension } \\
\cline { 2 - 5 } & $\begin{array}{c}\text { Avg. val., } \\
\mathrm{N} / \mathrm{cm}\end{array}$ & $\begin{array}{c}\text { The coefficient of } \\
\text { variation, } \%\end{array}$ & $\begin{array}{c}\text { Avg. val., } \\
\mathrm{N} / \mathrm{cm}\end{array}$ & $\begin{array}{c}\text { The coefficient } \\
\text { of variation, } \%\end{array}$ \\
\hline Volga-3 & $457 / 390$ & $3,7 / 6,1$ & $17,2 /-$ & $4,1 /-$ \\
\hline Theza on lavtan & $526 / 466$ & $7 / 3,6$ & - & - \\
\hline Theza on lavtan & $542 / 362$ & $17,7 / 7,2$ & - & - \\
\hline TM-B & $533 / 549$ & $2,4 / 2,6$ & $24 / 32,3$ & $3,91 / 2,6$ \\
\hline TM-B & $526 / 504$ & $5,1 / 4,2$ & $28,8 / 33,7$ & $3,1 / 5,2$ \\
\hline
\end{tabular}

For comparison, the Volga-3 material was chosen (coating chlorosulfonated polyethylene and butyl rubber, reinforcing base - capron), and promising domestic material. Thesa (coating - polyvinyl chloride, reinforcing base - capron), and promising domestic material. Teza (coating - polyvinyl chloride, reinforcing base - lavsan). In our domestic practice, awning materials on synthetic rubbers have developed a great deal, while overseas PVC-based coatings account for almost half of all types of coatings. PVC-based coatings are characterized by increased weather resistance, they make it possible to obtain soft shells of tent constructions by welding panels with each other, and has rich possibilities for color solutions. The "Teza" material produced by the domestic industry in its properties exceeds other domestic tent materials and is not inferior to the best foreign tent materials. As can be seen from the comparison results, TM-B is not inferior to the best domestic samples in its physico-mechanical properties, and even exceeds the homogeneity of its properties. The 
material TM-B is more even in the direction of the warp and weft in comparison with the "Teza" material.

\section{Results and discussion}

In the course of scientific research the following results were obtained: firstly, the awning constructions have a huge potential for achieving unique expressive forms and solving various architectural problems. Secondly, for the development of this direction it is necessary to use complex constructive systems, the most complicated development of knots and fastenings, constant searches, research and creation of materials for the Defense Ministry of Russia. Also, the lack of domestic experience and innovative developments inhibits the development of this area in Russia. In addition, it should be noted that soft enclosing structures in awning structures create an extensive field for research by young specialists, which creates the potential for scientific and economic growth of this direction of architecture in Russia.

\section{Conclusions}

At the first stages of the development of tent structures in Russia and abroad, similarities were observed in the materials and types of structures used, but by using more highly technological methods of production and erection, for example, laser cutting, the quality of foreign soft enveloping structures was improved. In modern world practice, structures from the MO, possessing unusual, and often unique forms, covering huge spaces, can no longer be regarded as purely engineering objects. Strong examples of this are the awning structures in Japan [4]. Over time, soft enclosing structures have found application in largescale objects of national and international importance. So, in 1981 in Jeddah, Saudi Arabia, the airport King Abdul-Aziz was opened, in which innovative constructive solutions were applied. Load-bearing functions perform reinforced concrete pylons $50 \mathrm{~m}$ high, between which are tapered conical shells, (PTFE, "Teflon"), 45*45 m. The upper and lower markings of the shell are $45 \mathrm{~m}$ and $30 \mathrm{~m}$, respectively. The main functional purpose of the shell is shelter from solar radiation and the creation of an optimal microclimate due to natural aeration created by the temperature drop on the surface of the shell and below it ( 30

${ }^{\circ} \mathrm{C}$ ), which significantly reduced operating costs.

\section{References}

1. A.S. Makogon G.V. Kulikov, A.I. Kazmina, Actual problems of architecture, construction and energy saving, Simferopol: NAPKS, 24 (2012)

2. Yu. I. Blinov, Construction and architecture, 8 (1985)

3. A.A. Khayrullin, Kama State Engineering and Economics Academy (KPI), 2 (2007)

4. F. Otto, F.K Schleier. Tent and cable-stayed building structures, Moscow: Stroyizdat (1970)

5. V.A. Skopenko, Academic Bulletin UralNIIproject RAASN, 1 (2010)

6. F. Otto, R. Trostel, Pneumatic building structures. Design and calculation of structures from cables, nets, Moscow: Stroiizdat (1967)

7. G. Rüle, METAL, PLASTICS, CERAMICS, TREE, Moscow: Stroyizdat, 2 (1974) 
8. V.V. Ermolov, U.U. Byrd, E. Bubner, Pneumatic building structures, Moscow: Stroyizdat (1983)

9. ZAO Trust-Walter, Texlon System and CPC Walter, On-line: http://www.rostent.ru

10. Ivanovoiskozh (Ivanovo), On-line: http://www.ivanovoiskozh.ru

11. M.V. Kindinova, G.V. Kulikov, A.I. Kazmina, Actual problems of architecture, construction and energy saving, Simferopol: NAPKS, 24 (2012)

12. Guideline Mehler technologies «Technical guideline to permanent tensile architectures», On-line: http://www.mehler-texnologies.com

13. "Textile architecture precontraint 1002S-1202S-1302S-1502S», On-line: http://www.ferrari.arehitecture.com

14. The Serge Ferrari Group «Special issue Sports venues», Serge Ferrari newsletter flexible composite materials, 7 (2012), On-line: http://www.sergeferrari.com

15. V.N. Kupriyanov, Slick-tent materials for building structures.: MHTI name of V. I. Lomonosov (1978) 